\title{
The Durand Agreement in the Light of Certain Recent Interna- tional Conventions
}

\author{
By Ijaz Hussain
}

\section{Introduction}

Pakistan's north-western frontier with Afghanistan is known as the Durand Line. Negotiated in 1893 on behalf of the British Indian Government by Sir Mortimer Durand and Abdur Rahman the Amir of Afghanistan, this boundary line ${ }^{1}$ which is about 1200 miles long constitutes "as one of the best defined and most clearly recognized frontiers in the world ". ${ }^{2}$ It came about as a result of an agreement known as the Durand Agreement. ${ }^{3}$ Since the emergence of Pakistan in 1947 as an independent State on the map of the world, Afghanistan has on a number of grounds challenged the validity of the Durand Agreement and consequently the boundary line which resulted from it. Pakistan, on her part, has vigorously rejected the Afghan viewpoint and has claimed the said Agreement as a valid treaty having settled once and for all the boundary line between the two countries.

Little literature exists, ${ }^{4}$ let alone a single comprehenșive article on the subject, which

1 Following the Durand Agreement the Indo-Afghan frontier was actually demarcated, wherever physically possible by the erection of pillars, except at two places. The one exception which related to the Chitral border was rectified during World War II; whereas the second exception which pertained to the Khyber area was rectified in 1919. Sir Olaf Caroe, The Pathans: 550 B.C.-A.D. 1957, Union Book Stall, Karachi, 1973, p. 463.

2 Mujtaba Razvi, The Frontiers of Pakistan, National Publishing House Ltd.: Karachi/Dacca, 1971, p. 143.

3 Sir Charles Aitchison (ed.), A Collection of Treaties, Engagements and Sanads relating to India and Neighbouring Countries, Calcutta: Government of India Publication, 1929-33, vol. 13, no. 13 (Persia and Afghanistan), p. 256. The most important portion of the Durand Agreement reads as follows:

1. The eastern and southern frontier of His Highness' dominions, from Wakhan to the Persian border, shall follow the line shown in the map attached to this agreement.

2. The Government of India will at no time exercise interference in the territories lying beyond this line on the side of Afghanistan, and His Highness the Amir will at no time exercise interference in the territories lying beyond this line on the side of India.

The two foregoing articles show that the Agreement does not describe the Line as the frontier of India but as that of Afghanistan and forbids interference by either side beyond this Line. The British did not extend their administrative control to the frontier tribesmen on the Indian side but only their political control and excluded the Amir's authority in those territories. Olaf Caroe defends it in these words: "In the international aspect this was of no account, for the Amir had renounced sovereignty beyond this line". Olaf Caroe, The Pathans, supra note 1, p. 382.

4 There is dearth of articles which treat the subject under study from the Pakistani perspective. Authors like Burke (infra note 16) and Caroe (supra note 1) have briefly focussed on it in their books but obviously the treatment is inadequate. The best statement of the Af ghan position has been made by Poullada and Pazhwak 
looks upon the various grounds connected with the legality or otherwise of the Durand Agreement from the Pakistani perspective. The present paper proposes to fill in this lacunae. However its focal point of study is the two recent conventions, namely the 1969 Vienna Convention on the Law of Treaties ${ }^{5}$ (hereinafter refered to as Vienna Convention) and the 1978 Convention on Succession of States in respect of Treaties ${ }^{6}$ (hereinafter referred to as Convention on State Succession) which have incorporated provisions having bearing upon the aforesaid boundary treaty. The study from this specific angle is justified on the ground that these conventions (the former is in force since 1980 while the latter is not yet in force), ${ }^{7}$ which embody the most recent and the most authoritative statement of law in the areas that they address, more or less cover all the grounds which are invoked by Afghanistan in favour of its claim. ${ }^{8}$

whose complete references are as follows: L. Poullada, "Some international legal aspects of Pushtunistan dispute", Afghanistan 21(4):10-36; A. Pazhwak, Pakhtunistan: The Khyber pass as the focus of the new State of Pakhtunistan, London, 1953.

5 For the text of the Vienna Convention see UN Conference on The Law of Treaties - first and second sessions, official records, conference documents (sales no. E.70.V.5). Af ghanistan is not a party to the Vienna Convention though she has signed it (23 May 1969). Similarly Pakistan is not a party though she too has signed it (29 April 1970). ST/LEG/SER.E/1, Multilateral Treaties Deposited with the Secretary-General, 31 December 1981 , p. 619.

6 For the text of the Convention on State Succession see A/CONF.80/16/Add.2, UN Conference on Succession of States in respect of Treaties, of ficial records, conference documents, vol. 3 (UN publications, sales no. E.79.V.10). Neither Pakistan nor Afghanistan is a party to the Convention on State Succession though both signed it (10 January 1979). Multilateral Treaties, supra note 5, p. 626.

7 The Vienna Convention entered into force on 27 January 1980. Ibid., p. 619. As far as the Convention on State Succession is concerned, till 31 December 1983, 6 countries had ratified or acceded to it. It comes into force when 15 States ratify or accede to it (article 49). The States parties to it so far: Ethiopia 28 Mai 1980; Iraq 5 December 1979; Seychelles 22 February 1980 (a); Tunisia 16 September 1980 (a); Yugoslavia 28 April 1980; Morocco 31 March 1983 (a). ST/LEG/SER.E/2/ Multilateral Treaties Deposited with the SecretaryGeneral, 31 Dec. 1982, p. 658 and ST/LEG/SER.E/2/Add.1, ibid., 31 Dec. 1983, p. XXIII.2-1.

8 It is to be noted that the Afghans have argued that the Durand Agreement aimed at fixing a "sphere of influence" rather than effect a change of sovereignty. Since this important plea of "sphere of influence" is not covered by either of the two conventions, we have left it untreated in the text. For the present purposes we have the following comments to make. An examination of the Durand Agreement shows that it describes the eastern and southern border of Afghanistan on the Indian side as "frontier". According to the Webster's Third New International Dictionary the term "frontier" in its ordinary sence signifies a) "a demarcated boundary between countries"; b) "a boundary between territorial units". The term "boundary" according to the same dictionary means "something that marks a bound (as of a territory or a playing field)". In other words, despite the fact that the two terms are quite of ten used interchangeably as if they are synonymous, a "boundary" connotes a line whereas a "f rontier" indicates where one State ends and another begins. Thus a frontier of two States is given a clear and definite shape by virtue of a boundary line. The use of the specific word "f rontier" in paragraph 1 which was actually demarcated in the years following the conclusion of the Durand Agreement under a joint British-Afghan Boundary Commission shows in unambiguous terms that the said Agreement did not relate to a "sphere of influence" but to an international frontier between the two States. 


\section{Vienna Convention}

Dealing with the Vienna Convention first, there are four articles which are relevant here. These are articles 50, 52, 53 and 62(2) of part V which deal respectively with Corruption, Coercion, Jus Cogens and Rebus Sic Stantibus as grounds of invalidity of treaties.

\section{A) Corruption}

To begin with, it is claimed by the Afghans that the Durand Agreement was invalid on the ground that Amir Abdur Rahman was bribed into it by payment of a huge "subsidy". In their opinion, the payment of subsidy which is a kind of bribery struck at the Agreement and vitiated it with nullity as laid down in article 50 of the Vienna Convention ${ }^{9}$ which is worded as follows:

\section{Article 50 - Corruption of a representative of the State}

If the expression of a State's consent to be bound by a treaty has been procured through the corruption of its representative directly or indirectly by another State, the State may invoke such corruption as invalidating its consent to be bound by the treaty.

Before emarking upon an examination of this argument, it may be necessary to say a word about the institution of subsidy. During the colonial period, the British were involved in the practice of dishing out sums of money, sometimes quite large, to rulers of semi-autonomous States with the view to promoting their political, economic and security interests. The practice which was not too restricted was not viewed in terms of bribery. The rough equivalent of subsidy in today's world would be economic aid, especially grants made by rich States to developing countries. These aids like subsidy are instruments in the hands of donor countries to influence the policies of recipient States but their payment is not régarded as an act of bribery.

The Amirs of Afghanistan since Dost Muhammad had been recipients of subsidy from the British Government. This subsidy was obviously paid with the view to buying their

9 It is noteworthy that Afghanistan has also contested the validity of the Durand Agreement on the ground that the Afghan consent to it was obtained in violation of article 49 of the Vienna Convention which provides: "If a State has been induced to conclude a treaty by the fraudulent conduct of another negotiating State, the State may invoke the fraud as invalidating its consent to be bound by the treaty". It was perhaps due to this that during the Conference on the Law of Treaties the Afghan representative supported the retention of the foregoing article on the ground that "the low technological level of the developing countries that were primarily affected by those treaties, increased the opportunities for fraudulent practices" (UN Conference on the Law of Treaties, first session, of ficial records, summary records of the plenary and the committee of the whole meetings, p. 259, para 2.). However, an examination of the relevant facts, including the memoirs of Amir Abdur Rahman, with bearings on the conclusion of the Treaty in question do not support this contention. 
friendship. The British would not have paid it if it was not to their advantage. It was paid to the public treasury of Afghanistan and not to the Amir personally. The Afghan rulers mostly spent the money received in purchasing arms and war materials from Britain. This is how Amir Abdur Rahman looked at it:

... I get 18 lakhs of rupees annually from the Indian Government, and therefore I must not have any representative in London. Now, I did not accept this subsidy on any such condition; It is given to me for various reasons... The payment of this subsidy does not minimise my dignity: on the contrary it raises the value of my friendship, and England does not give her money in vain. ${ }^{10}$

The foregoing statement shows that Amir Abdur Rahman did not look upon the grant of subsidy as an act of bribery. Those who are familiar with the Afghan social history know that an Afghan can sacrifice anything for the sake of dignity. With this background it is inconceivable to imagine that Amir Abdur Rahman would have accepted a subsidy if its acceptance had amounted to corrupting him or his compatriots would have continued to accept him as the Amir if it was viewed as such. Therefore the raising of subsidy from 12 lakh to 18 lakh rupees following the conclusion of the Durand Agreement did not amount to bribery. At least neither the Amir nor his fellow countrymen regarded it as such. In fact, payment of subsidy to the Afghan rulers was so much part of the AngloAfghan political relations at that time that whenever the British contemplated its discontinuance the Afghans looked upon it with disfavour. For example, during the peace negotiations after the third Anglo-Afghan War when te British indicated their desire to stop payment of subsidy in view of their new relationship, the Afghans opposed it. ${ }^{11}$ In the light of the foregoing, it is obvious that provisions of article 50 do not apply to the Durand Agreement because it is not proved that the payment of enhanced subsidy amounted to corrupting Amir Abdur Rahman.

\section{B) Coercion}

One of the principal arguments on which the Afghan case for the invalidity of the Durand Agreement rests is that its conclusion was obtained through duress. ${ }^{12}$ In this view, Amir Abdur Rahman, the Afghan king who signed the said Agreement, was not a

10 Abdur Rahman, The Life of Abdur Rahman, Amir of Afghanistan, John Murray: London, 1900, 2 vols., II:256, see also p. 114.

11 Ludwig W. Adamec, Afghanistan, 1900-1923, University of California Press: Berkeley and Los Angeles, 1967, p. 129.

12 Af ghanistan has also challenged the validity of the Durand Agreement on the ground of its violation of article 51 of the Vienna Convention which states: "The expression of a State's consent to be bound by a treaty which has been procured by the coercion of its representative through acts or threats directed against him shall be without any legal effect". However, this contention is not supported either by the memoirs of Amir Abdur Rahman nor by other relevant facts. 
free agent as all sorts of pressures, military, political and economic were exerted against him in order to get his consent to it. The British, who had monoply of the commercial trade and the trade in arms and ammunition from India into Afghanistan at that time, had made a veiled threat of embargo against the latter. They were also building a network of roads and railroads in the tribal territory leading to the Afghan border in pursuance of their expansionist and aggressive "forward policy". On top of it, they sent a letter to the Amir in which they asked for demarcation of the boundary with India which was interpreted by the Amir as an ultimatum. It is contended that in view of the foregoing circumstances under which the Durand Agreement took place, article 52 of the Vienna Convention which is given below would render it invalid ab initio:

\section{Article 52 - Coercion of a State by the threat or use of force}

A treaty is void if its conclusion has been procured by the threat or use of force in violation of the principles of international law embodied in the Charter of the United Nations.

According to the terms of article 52, the concept of coercion is restricted to "a threat or use of force" in violation of the principles of the UN Charter. Some members of the International Law Commission wanted to extend the scope of this article by bringing other forms of pressure, such as economic measures designed to strangle the economy of a country, within its compass. They proposed to do so by specifically mentioning them in the body of the article. This viewpoint did not find favour with the Commission and the present formulation of "a threat or use of force" was retained. ${ }^{13}$ However, the Commission was of the view that the interpretation of the relevant Charter provisions would in practice determine the exact scope of the article.

During the first session of the Conference on the Law of Treaties, Afghanistan along with eighteen other developing countries moved an amendment ${ }^{14}$ (A/CONF. 39/C. 1/L. 67/Rev. 1/Corr. 1) which aimed at extending the scope of the concept of coercion by making a treaty void additionally on the ground of economic and political pressure. It was not incorporated in the text of article 52 but was instead adopted as a declaration at the 20th plenary meeting. It is interesting to observe that Pakistan was one of the co-sponsors of the foregoing amendment. Presumably Afghanistan wanted the scope of article 52 to be broadened with the view to covering its position on the Durand Agreement and other related agreements. It is not clear why Pakistan agreed to become a co-sponsor of this amendment. Perhaps all is well that ends well from the Pakistani viewpoint and the scope of article 52 is to be viewed in the sense in which it is at present formulated.

Now examining the foregoing Afghan contention it would be necessary to make an historical investigation into the circumstances surrounding the events which led to the

13 A/AC.4/SER.A/1966/Add.1, Yearbook of the International Law Commission, 1966, vol. II, p. 246, para. 3.

14 UN Conference on the Law of Treaties, first session, supra note 9, pp. 269-70, paras. 21-6; ibid., second session, p. 93, para. 5; and pp. 100-01, paras, 1, 2 and 12. 
signing of the said Agreement in order to discover whether or not coercion was employed in obtaining it.

One way of looking at this question is to see the status in history of the territories which were supposedly detached from the Amir's empire and became part of the British Indian empire as a result of the Durand Agreement. These territories which are today comprised in the so-called "Pakhtunistan ${ }^{15}$ were either part of the different Indian empires like the Mauryan, the Kushan, the Moghul and the British or at times came under the sway of rulers like Mahmud of Ghazni, Timur and Nadir Shah whose hold on them was anything but permanent. They were also part of the vast empire of Ahmad Shah Durrani, the first Afghan king of a united and independent Afghanistan which became a reference point in terms of territorial boundaries of Afghanistan for his successors, especially the laterday rulers and explains the Afghan demand for "Pakhtunistan". Ahmad Shah's empire started disintegrating during his life time and following his death it could not be held together by his successors. By the time Dost Muhammed became the Amir in 1826, his effective control over Afghanistan was confined to 100 miles around Kabul. The Peshawar valley had been ceded to the Sikhs in 1823 by his predecessor which was later on taken over from them in 1849 by the British. Through the Treaty of Gandamak (1879) Amir Yaqub Khan surrendered Kurram, Pishin, Sibi and the control of the Khyber and Michini passes to the British. Subsequently when a renunciation of these territories took place in favour of the British through the Durand Agreement, Amir Abdur Rahman was not losing any area which belonged to him. They were already part of the British Indian empire. This argument is reinforced by the fact that Abdur Rahman took over as Amir of Afghanistan on the condition that he would not question the "arrangements with regard to the north-west frontier which were concluded [by the Treaty of Gandmak]". In the light of foregoing the argument of coercion does not hold for the reason that the territories in question never belonged to Amir Abdur Rahman. ${ }^{16}$

Another way of evaluating the validity or otherwise of this contention is to resort to the memoirs of Amir Abdur Rahman in which he has, fortunately for us, shed ample light on the issue. Dwelling on the subject, the Amir relates ${ }^{17}$ that in the map sent to him by the Viceroy in connection with demarcation of the Afghan frontier with India, certain areas inhabited by frontier tribesmen which he termed as "Yaghistan" (the land of the unruly) were shown as belonging to India. The Amir wrote back to the Viceroy whereby he urged him to let the people of these territories stay with him for at least two reasons.

15 "Pakhtunistan" signifies different things to different people. To some it means nothing more than an expression of concern for the welf are of the Pakhtun tribes but without any territorial claims. To others it signifies claim on the territories inhabited by Paghtuns on the Pakistan side of the Durand line for the purpose of uniting them with those on the Afghan side. According to still others it would mean Af ghan claim not only on the territories inhabited by Pakhtuns but also on those inhabited by their ethnis cousins Baluchs so that Afghanistan has direct access to the Arabian Sea.

16 For a more comprehensive treatment of this point see S. M. Burke, Pakistan's Foreign Policy, Oxford University Press: Karachi, 1973, pp. 76-81.

17 Abdur Rahman, The Life of Abdur Rahman, supra note 10, II:154:64. 
Firstly, he pleaded that being of the same faith as they, he would make them fight against any enemy of England in the name of jihad. He thought that he was in the best position to pacify them and make them useful friends of England. He argued that in case they were detached from him, they will not be of any use either to him or to the British. Secondly, he maintained that in case these frontier tribes who shared the same nationality and religion as he were taken away from his jurisdiction, his prestige would suffer in the eyes of his subjects which would render him weak. He held that his weakness was injurious for the British Government. The latter did not see eye to eye with this viewpoint and ultimately the boundary line which was agreed upon between the two extended from Chitral and Baroghil Pass to Peshawar. By virtue of the Durand Agreement, Amir Abdur Rahman renounced claims to the railway station of New Chaman, Chagai, part of Waziri, Bulund Khel, Kurram, Afridi, Bajaur, Swat, Buner, Dir, Chilas and Chitral. The picture that emerges from the foregoing facts on the face of it suggests that Amir Abdur Rahman concluded the Durand Agreement and ceded the territories that he did somewhat reluctantly. However, a careful perusal of the case in the context of the overall objectives of the Amir as they come out in his memoirs suggests that on balance the said Agreement was the result of consent and free will rather than that of coercion and lack of free will. The Amir was engaged on the task of consolidating Afghanistan into one nation and for this purpose he needed peace on the borders because, in his view, both the British and the Russians would not push beyond clearly defined borders. In other words, the constraints under which he negotiated were nullified by the advantages that he had fixed for his country and therefore his free will was not suppressed as a result. Here below follows a description of the historical perspective in which Amir Abdur Rahman operated..$^{18}$

In early 19th century the dominant European powers in Asia, namely the British and Russian empires, because of their ever expanding frontiers, came face to face with each other which starting from the Chinese frontier went down to the Oxus across the Kara Bel plateau to the Hari Rud valley and the frontiers of Persia. In its onward drive, if the Russian empire gobbled up Khirghiz and Turkmen and reduced Khiva and Bukhara as mere vassal states, the British empire in India having swallowed Punjab and Sind, and having got its supremacy acknowledged in Kashmir, Chitral and Kalat was openly manifesting its desire to control the approaches to India located in Afghanistan. The Russian drive to the south and the British expansion northward were looked upon with mutual suspicion and fear by the two empires as posing threat to their respective interests. To the British, any Russian advance in Central Asia was construed as a potential threat to India; whereas to the Russians, any British attempt to establish itself north of the Hindu Kush was a clear signal to dislodge the former from its Central Asian possessions. The mutual suspicions and the efforts by each to frustrate the real or

18 See Fraser-Tytler, Afghanistan, Oxford University Press: London, 1967, pp. 75-180; Vartan Gregorian, The Emergence of Modern Afghanistan, Stanf ord University Press: Stanford/California, 1979, pp. 91-118; Olaf Caroe, The Pathans, supra note 1, pp. 346-59 and 370-89. 
perceived designs of the other on its territorial possessions came to be known as the "Great Game".

As far as the British response to the Russian designs on India was concerned, it consisted of two extreme views. On view termed as the "forward policy " advocated making Quetta if not Herat as the outer post of India's defence. In other words, Afghanistan was to constitute the frontier of India with a view to its defence against any Russian territorial aggrandizement and all European nations were to be excluded from carrying on commercial or political activities in Afghanistan. The other view baptized as "stationary policy" pleaded for a retreat to the Indus for the purposes of meeting India's security concerns. The focal point of this alternative approach was the so-called "masterly inactivity" behind a closed door and cessation of all dealings with Afghanistan. The basis of this policy was that it would ensure Britain a better hold over India by promoting trade and by providing greater security.

The British policy alternated between these two radical strategies during 1936-80. With the advent of Lord Auckland as the Governer-General of India in the late 1930s, the "forward policy" was put in operation which saw its high-water mark during the first Anglo-Afghan War in 1939. After the war in which the British were defeated, especially during the period 1955-74 started a reaction against the "forward policy" and a period of "masterly inactivity" set in. During 1974-80 again the "forward policy" school of thought was in ascendancy which touched its zenith in the second Anglo-Afghan War which came to an end in May 1879 by the Treaty of Gandamak. By the terms of this treaty Afghanistan ceded large territories and, inter alia, came under the British sphere of influence as Amir Yaqub Khan agreed to accept the British overlordship in matters pertaining to Afghanistan's external relations.

As far as the Russian response to the real or supposed British designs on Central Asia was concerned, it consisted of "forward policy" of its own. Some Russian strategists were of the view, especially during the 1870s when Disraeli was advocating "forward policy" against Russia, that Herat be handed over to Persia and that the Hindu Kush instead of the Oxus constitute the frontier between the Russian and British empires. Additionally, they advocated annexation of northern Afghanistan because they considered it as a natural and necessary frontier for the defence of its Central Asian possessions. Another group of Russian strategists held that the Transcaspian railway be extended to Herat and Kandahar as such a move would induce Great Britain to abandon her anti-Russian policies in Europe and bring about a settlement between the two.

In the face of the expansionist and aggressive designs of the two neighbouring empires, Afghanistan desperately sought to settle its borders with Russia and British India. In 1869 Amir Sher Ali unsuccessfully tried to seek from Lord Mayo, among others, a guarantee of his boundaries against Russian advances. Ultimately the Anglo-Russian Agreement of October 1872 tacitly accepted the Amir's territories up to the Amu Darya (Oxus) and down to Khoja Saleh. Afghanistan's northwestern frontier with Russia was settled in July 1887 and the final protocol was signed at St. Petersburg, even though Afghanistan lost Panjdeh to Russia in the process. Similarly, Amir Abdur Rahman 
earnestly sought the despatch of a British mission for the settlement of boundary question with India. This was finally achieved when Sir Mortimer Durand came to Afghanistan and successfully negotiated in 1893 an agreement which subsequently came to be known as the Durand Agreement.

The historical context as described above in which Amir Abdur Rahman negotiated the settlement of boundary disputes with Afghanistan's mighty neighbours reveal that he was able to achieve what he had set out to do. And this could not have been done to his satisfaction had his free will been warped. This is supported by the testimony of Amir Abdur Rahman who has made the following comments on this point:

At the same time when I was occupied in breaking down the feudal system of Afghanistan and moulding the country into a strong consolidated kingdom, I was not unaware nor neglectful of the necessity of defining my boundaries with the neighbouring countries. I well knew that it was necessary to mark out the boundary lines between my dominions and those of my neighbours, for the safety and protection of my kingdom, and for the purpose of putting a check on their advances, and getting rid of misunderstandings and disputes. ${ }^{19}$

Following the conclusion of the Agreement in which Afghanistan "renounced its claim in a friendly spirit", ${ }^{20}$ the Amir in a public Durbar "praised God for bringing about the friendly relations which now existed between the two Governments and putting them on a closer footing than they had been before $"{ }^{21} \mathrm{He}$ also thanked "Sir Mortimer Durand and the other members of the Mission for their wise way of settling the disputes ". ${ }^{22}$ The conclusion that one draws from the foregoing is that the "threat or use of force" of which article 52 of the Vienna Convention refers to is found lacking in the above situation. It is perhaps because of the laudatory remarks of the memoirs towards the British Government on its attitude regarding the boundary settlement that the relevant portion of the foregoing document has been termed as fake by some Afghan scholars. ${ }^{23}$ Proceeding on the assumption that our analysis of the circumstances as described above is vitiated as suffering from subjectivism or conceding that the allegation of fakeness is justified, we propose to reevaluate the whole issue on the hypothesis that Amir Abdur Rahman negotiated the Durand Agreement under duress. Even then our conclusion remains unchanged, i. e. that the Agreement is valid and binding. The reason behind this conclusion is the fact that in the view of the International Law Commission article 52 does not have retroactive effect on the validity of treaties concluded before the establishment of the modern law. This is how the Commission has explained this point:

19 Abdur Rahman, The Life of Abdur Rahman, supra note 10, II:146; see also p. 149 und p. 154.

20 Ibid., p..161.

21 Ibid., p. 162.

22 Ibid.

23 V. Gregorian, The Emergence of Modern Afghanistan, supra, note 18, p. 129, footnote; see also L. Dupree, Afghanistan, Princeton University Press: Princeton/New Jersey, 1973, p. 426. 
A juridical fact must be appreciated in the light of the law contemporary with it. The present article concerns the conditions for the valid conclusion of a treaty - the conditions, that is, for the creation of a legal relation by treaty. An evolution of the law governing the conditions for the carrying out of a legal act does not operate to deprive of validity a legal act already accomplished in conformity with the law previously in force. The rule codified in the present article cannot therefore be properly understood as depriving of validity ab initio a peace treaty of other treaty procured by coercion prior to the establishment of the modern law regarding the threat or use of force. ${ }^{24}$

Regarding the date from which the modern law is to be considered as in force, the Commission stated that the great majority of international jurists considered article 2, paragraph 4, along with some other provisions of the UN Charter as making an authoritative enunciation of the modern customary law regarding the threat or use of force. In its view, "the present article, by its formulation, recognizes the implication that the rule which it lays down is applicable at any rate to all treaties concluded since the entry into force of the Charter". ${ }^{25}$

In short, it may be said that it is not proved that the Durand Agreement was signed under duress; and if it was, the Agreement is not rendered invalid for the simple reason that the provisions of article 52 which forbids the conclusion of a treaty under duress do not apply retroactively at least to the period under discussion.

\section{C) Jus cogens}

The next ground that we find in the Vienna Convention which could render the Durand Agreement invalid is based on the provisions of article 53 which deals with the concept of jus cogens. In other words, in this view the Durand Agreement is void because it is in conflict with the right of self-determination which has the character of jus cogens. Before proceeding further here below follows the provisions of article 53:

\footnotetext{
Article 53 - Treaties conflicting with a peremptory norm of general international law

A treaty is void if, at the time of its conclusion, it conflicts with a peremptory norm of general international law. For the purposes of the present Convention, a peremptory norm of general international law is a norm accepted and recognized by the international community of States as a whole as a norm from which no derogation is permitted and which can be modified only by a subsequent norm of general international law having the same character.
}

To begin with, to view the principle of self-determination in terms of jus cogens (peremptory norm) presupposes that it existed at some stage in its historical evolution as

24 ILC Yearbook, supra note 13, p. 247, para. 7. Emphasis original.

25 Ibid., para. 8. 
jus (right). ${ }^{26}$ However, a brief review of its development in historical perspective shows that it has not been decisively settled that the principle of self-determination has in today's world the status of a legal right.

This principle was first propounded ${ }^{27}$ to the international community in the course of World War I by President Wilson in his Fourteen Points and Four Principles. However, at the Peace Conference which followed World War I, the principle of self-determination was applied selectively and the colonies of the Allied Powers were spared from its application. Nor was this principle enshrined in the League Covenant. After World War II, the UN Charter mentioned it at two places in articles 1 and 55. Subsequent landmarks in this respect were the 1958 Resolution on Self-Determination and the 1960 Declaration on Colonialism as well as a plethora of other General Assembly resolutions relating to the subject of self-determination. The UN Covenants on Civil and Political Rights and on Economic, Social and Cultural Rights each affirms it in its article 1. Despite these important developments on the subject, international jurists are divided as to whether or not the principle of self-determination has acquired a legal character. The International Court of Justice as the highest judicial organ in the world in its 1971 advisory opinion on Namibia almost accepted this principle in terms of a legal right. ${ }^{28}$ In short, the principle possibly stands accepted as a legal right but the full and unqualified weight of authority in the matter is perhaps still lacking.

If the principle of self-determination is grudgingly accepted as a legal right, can it be viewed in terms of jus cogens? The International Law Commission in its commentary ${ }^{29}$ on article 53 admitted the absence of a simple criterion with which a general rule of international law could be identified as possessing the jus cogens character. It also emphasized that most of the general rules of international law lacked that character. Some members of the Commission suggested the following examples "as the most obvious and best settled rules of jus cogens": 1) unlawful use of force; 2) performance of an act criminal under international law; 3 ) commission of acts which would require the cooperation of every State to suppress the commission of acts like trade in slaves, piracy or genocide. Others suggested, inter alia, the principle of self-determination "as other possible" example. It is clear from the Commission's commentary that its members did not look upon the principle of self-determination as a settled and noncontroversial example of jus cogens. It was cited as no more than another "possible" example. Anyhow when the World Court has hesitated to put all its weight of authority in favour of accepting this principle as a legal right and the International Law Commission has failed to treat this principle among the candidates of first order as examples of jus cogens, the

26 M. Pomerance, Self-Determination in Law and Practice, Martinus Nijhoff: The Hague/Boston/London, 1982, chapter 9.

27 U. O. Umozurike, Self-Determination in International Law, Archon Books, 1972, chapter 1.

28 O. J. Lissitzyn, "International law and the advisory opinion on Namibia", Columbia Journal of Transnational Law 11 (Winter):291.

29 ILC Yearbook, supra note 13, p. 248. 
argument that the Durand Agreement is void as being in conflict with article 53 does not hold.

Doctrinal discussion on the principle of self-determination apart, it may be pertinent to note here that in accordance with the Indian Independence Act of 1947 a referendum was held in the North-West Frontier Province and the tribal areas in order to determine whether the people inhabiting there wanted to join India or Pakistan after the departure of the British from the Sub-Continent. In this referendum in which slightly more than $50 \%$ of the electorate voted people opted for Pakistan by casting 289, 244 votes in her favour against 2,874 for India.

Afghanistan made objections against this referendum claiming ${ }^{30}$ that in violation of the Indian Independence Act of 1947 people were forced to choose between India or Pakistan and the third alternative to seek national independence was denied to them. She further maintained that this referendum was strongly opposed as more than $50 \%$ of the people in the administered areas and the party in office boycotted the proceedings, thus rendering it completely devoid of any legal content.

An analysis of the foregoing referendum shows that the Afghan objections were unfounded. As far as the first objection is concerned, it is true that the people of the area had to choose between India and Pakistan and the option to become independent was not given to them. But this was in accordance with the partition plan which sought to know whether the population of the North West Frontier Province which was about $92 \%$ Muslim but where pro-India Congress Government ruled wanted to join India or Pakistan. Given this framework there was no logic to insert any other option. As far as the second objection is concerned, on the basis of $50 \%$ voter turnout it is not fair to say that $50 \%$ of the electorate boycotted the elections. In fact $100 \%$ voter turnout is unheard of and $50 \%$ is fairly high even by Western standards. In the previous provincial legislative elections of 1946 which returned the Congress supported Government to power the voter turnout was $68 \%$. The Hindus and Sikhs of the NWFP who counted about $13 \%$ of the registered voters and who most probably voted in the 1946 elections did not participate in the referendum. The percentage of the voter turnout in the referendum when added to the percentage of the boycotting Hindu and Sikh voters almost brings it to the percentage of the voter turnout in the 1946 elections. In the light of the foregoing it is not justified to say that the referendum was devoid of legal content.

\section{D) Rebus sic stantibus}

The fourth and the last ground which could invalidate the Durand Agreement is to be found in article 62 of the Vienna Convention which provides that under certain conditions a fundamental change of circumstances (rebus sic stantibus) could be invoked to terminate or withdraw from a treaty if it (the change) related to those (circumstances)

30 ST/LEG/SER.B/14, UN Legislative Series, Materials on State Succession, (sales no. E/F.68.V.5), p. 2. 
which existed at the time of the conclusion of a treaty and which was not foreseen by the parties. Article 62, paragraph 2(a), however, adds that the plea of a fundamental change of circumstances would not be available for the purposes of terminating or withdrawing from a treaty establishing a boundary. Article 62 is worded as follows:

\section{Article 62 - Fundamental change of circumstances}

1. A fundamental change of circumstances which has occurred with regard to those existing at the time of the conclusion of a treaty, and which was not foreseen by the parties, may not be invoked as a ground for terminating or withdrawing from the treaty unless:

a) The existence of those circumstances constituted an essential basis of the consent of the parties to be bound by the treaty; and

b) The effect of the change is radically to transform the scope of obligations still to be performed under the treaty.

2. A fundamental change of circumstances may not be invoked:

a) As a ground for terminating or withdrawing from a treaty establishing a boundary ...

Apparently, the foregoing article instead of invalidating the Durand Agreement by virtue of its paragraph 2(a) accepts it as a valid document. However, the Afghan posi$\operatorname{tion}^{31}$ on this article is quite interesting. To begin with, in the course of the Vienna Conference on the Law of Treaties in 1968 and 1969, her representative opposed the incorporation of paragraph 2(a) on the ground that it would sacrifice the interests of nations and individuals at the altar of stability of treaties. He was of the opinion that its adoption would amount to endorsing past treaties of colonial and unequal nature and would also weaken the rule of jus cogens. He favoured preservation of stability of boundary treaties but only when they were lawful and accepted by the parties concerned. However he failed to bend the Conference to his viewpoint and his attempt to get paragraph 2(a) $)^{32}$ deleted fizzled out. At the end of the Conference Afghanistan made a declaration in which she stated her understanding of the article in question. According to her, ${ }^{33}$ paragraph 2(a) relates neither to unequal and illegal treaties nor to treaties which are in violation of the principle of self-determination. In other words, in Afghanistan's view, the exception contained in paragraph 2(a) to the principle of rebus sic stantibus applies only to treaties which are valid. In her opinion since the Durand Agreement suffered from invalidity, the foregoing exception would not apply to it and the principle of rebus sic stantibus would operate in the present situation.

31 UN Conference on the Law of Treaties, first session, supra note 9, p. 373, paras. 27-9; ibid., second session, p. 118, paras. 19-22.

32 Article 62 was adopted by the Conference by 93 votes to 3 with 9 abstentions. Afghanistan was amongst those who voted against (Ibid., second session, p. 121, paras. 47 and 50-1). It is to be noted that Pakistan favoured retention of para. 2(a) on the ground that a party should not be allowed to take advantage of its own wrong doing. She favoured the application of article 62 through an independent and impartial adjudication. Ibid., first session, pp. 376-77, paras. 80-3.

33 Multilateral Treaties, supra note 5, p. 620. 
A perusal of the International Law Commission's commentary ${ }^{34}$ on article 62 shows that the Afghan interpretation is somewhat misplaced. Actually some members of the Commission were of the view that the total exclusion of treaties establishing a boundary from the ambit of the rule of rebus sic stantibus might be inconsistent whith the principle of selfdetermination contained in the UN Charter. The Commission did not go along with this contention on the ground that acceptance of their viewpoint might become a source of dangerous frictions rather than an instrument of peaceful change which is the real purpose of the rule. Arguing that the principle of self-determination as enshrined in the UN Charter had an independent existence, it held that any presentation of it as an application of the rebus sic stantibus rule would lead to confusion. However, the Commission made it clear that the foregoing exception would not exclude the operation of the principle of selfdetermination wherever it was relevant.

\section{Convention on State Succession}

\section{A) Boundary regimes}

The other recent convention which has incorporated provisions bearing upon the Durand Agreement is the 1978 Convention on State Succession whose article 11 is relevant. The said article reads as follows:

\section{Article 11 - Boundary regimes}

A Succession of States does not as such affect

a) a boundary established by a treaty; or

b) obligations and rights established by a treaty and relating to the regime of a boundary.

The meaning and implication of the above article for the Durand Agreement can be properly appreciated only in the context of the general philosophy of the Convention on State Succession. This philosophy which is known as the "clean-slate principle" though

34 ILC Yearbook, supra note 13, p. 259, para 11. In the course of debate on article 62 during the first session of the Conference, the Expert Consultant, Sir Humphrey Waldock reiterated the Commission's position in these words:

The Afghan representative had asked what was the relation between that provision [paragraph 2 (a)], and self-determination, and illegal and unequal colonial treaties. The answer had to be found in the present convention itself. The question of illegality in the dealt with in the two articles treating of $j u s$ cogens... In the Commission's view, self-determination was an independent principle which belonged to another branch of international law and which had its own conditions and problems.

UN Conference on the Law of Treaties, first session, supra note 9, p. 381, para. 31. 
recurring throughout the Convention is to be found generally in article $16 .{ }^{35}$ It prescribes that a newly independent State embarks on international life free from the obligation to be bound by any treaty, contracted on its behalf by the predecessor State, which was previously applicable to its territory. In other words, this general philosophy lays down the principle of tabula rasa for a newly independent State so that is could operate in the international community unencumbered by any previous obligations. However, realizing that an unfettered application of this principle would create a whole plethora of international problems of juridical nature, the Convention has sought to balance it through the incorporation of the "Continuity principle". The latter principle which is mainly provided in articles 11 and $12^{36}$ suggests that, in certain treaty matters, a newly independent State is not absolved from the obligations undertaken by the predecessor State on its behalf and which have devolved upon it. Perhaps the most important example of such obligations is referred to in article 11 according to which treaties of a territorial character fall in a special category and remain unaffected by the occurrence of a succession of States. This traditional doctrine which is supported by modern jurists is introduced in terms of an exception to the "clean-slate principle".

It is to be noted that article 11 finds its antecedents in article 62, paragraph 2(a) of the Vienna Convention which, as we have seen above, lays down that the principle of rebus sic stantibus is not applicable to a treaty whereby a boundary is established. Though 100th articles are similar in nature, they have a different contextual framework. Whereas article 62, paragraph 2(a) emphasizes the inviolability of boundaries as part of the general law of treaties, article 11 , on the other hand, takes care of situations resulting from a succession of States. However, article 11 is an extension of article 62, paragraph 2(a) as acknowledged by the International Law Commission itself in these words:

The considerations which led the Commission and the Conference to make this exception to the fundamental change of circumstances rule appear to apply with the same force to a succession of States, even though the question may have presented itself in a different context. Accord-

35 Article 16 - Position in respect of the treaties of the predecessor State

A newly independet State is not bound to maintain in force, or to become a party to, any treaty by reason only of the fact that at the date of the succession of States the treaty was in force in respect of the territory to which the succession of State relates.

36 Article 12 - Other territorial regimes

1. A succession of States does not as such affect:

a) obligations relating to the use of any territory, or to restrictions upon its use, established by a treaty for the benefit of any territory of a foreign State and considered as attaching to the territories in question;

b) rights established by a treaty for the benefit of any territory and relating to the use, or to restrictions upon the use, of any territory of a foreign State and considered as attaching to the territories in question.

2. A succession of State does not as such affect:

a) obligations relating to the use of any territory, or to restrictions upon its use, established by a treaty for the benefit of a group of States or of all States and considered as attaching to that territory;

b) rights established by a treaty for the benefit of a group of States or of all States and relating to the use of any territory, or to restrictions upon its use, and considered as attaching to that territory.

3. The provisions of the present article do not apply to treaty obligations of the predecessor State providing for the establishment of foreign military bases on the territory to which the succession of States relates. 
ingly, the Commission considers that the attitude of States towards boundary treaties at the United Nations Conference on the Law of Treaties is extremely pertinent also in the present connexion. ${ }^{37}$

A perusal of article 11 shows that, like article 62, paragraph 2(a), it does not prima facie support the argument of invalidity of the Durand Agreement. However, Afghanistan's understanding of article 11 is quite interesting. To begin with, ${ }^{38}$ both in the Conference on the Law of Treaties and outside it whenever and wherever the provisions of the present article were debated Afghanistan opposed them. Here her representative favoured the deletion of articles 11 and 12 on the ground that, as argued by him, a) they fell in the area of succession in respect of rights and duties resulting from sources other than treaties rather than succession of States in respect of treaties; b) that their incorporation would amount to prejudging a boundary dispute where one of the parties refused to accept unequal or colonial treaties on the ground of the right of self-determination. Failing in this endeavour, the Afghan representative pleaded for the merger of the two articles $^{39}$ on the basis that since a boundary was not only a geometrical line but also comprised a human element which was not reflected by the term "boundary", the merger approach would have the benefit of covering territorial regimes in a single article. However, his advocacy for merging the two articles did not produce desired results and was abandoned without a vote being taken on it.

As far as article 11 in its present formulation is concerned, Afghanistan looks upon ${ }^{40}$ its subparagraph (a) which is worded "boundary established by a treaty" to mean "boundary validly established by a valid treaty". In her view, the underlying assumption of the rule contained in article 11 was "to refer to situations lawfully and validly created". Pursuing this line of thinking she has maintained that the foregoing article did not rule

37 UN Conference on Succession of States, supra note 6, p. 29, para. 10.

38 A/CONF.80/16, UN Conference on Succession of States in respect of Treaties, first session, official records, summary records of the plenary and the committee of the whole meetings, vol. 1, pp. 113-15, paras. 10-20.

39 Ibid. During the first session of the Conference Afghanistan moved an amendent (A/CONF.80/C.1/L.24) by virtue of which she sought to replace the title of article 11 "Boundary regimes" and the title of article 12 "Other territorial regimes" by a title reading as follows: "Territorial regimes" ( UN Con ference on Succession of States, supra note 6, p. 154). The Afghan amendment was purely of a drafting and procedural nature. Yielding to the majority's opinion in the Conference which was opposed to the merging of articles 11 and 12 , she was prepared to withdraw subparagraph (b) of his country's amendment but still wanted the two articles to have the same title (UN Conference on Succession of States, first session, supra note 38, p. 140, paras. 1 and 2). Articles 11 and 12 were adopted by the Conference without merging them and the Afghan amendment was virtually withdrawn.

40 UN Conference on Succession of States, first session, supra note 38, pp. 113-15, paras. 10-20. It is noteworthy that the Pakistan delegate held that the question of the validity of a treaty was a separate question which was covered by article 14 . He believed that it was to be decided objectively in the light of the Vienna Convention (Ibid., p. 118, para. 48). The Expert Consultant, Sir Francis Vallat, did not comment on it as, he thought, he had covered it as far as possible in the ILC commentary on the draft convention. On the issue whether or not a boundary was "validly established ", he made the observation that "a treaty either established a boundary or it did not, and that if a boundary was in fact established, it was presumably validly established". He stated that he would have preferred the expression "lawf ully and validly created" in subparagraph (a) of article 11. Ibid., p. 123, para. 48. 
out any adjustment through self-determination, negotiation, arbitration or any other method acceptable to the parties concerned.

Additionally, Afghanistan refuses ${ }^{41}$ to look upon article 11 as an independent article but rather subjects its operation to certain other articles of the Convention on State Succession. Thus she interprets article 11 in the light of articles 6 and 14. Before proceeding further on the point under discussion the provisions of the latter two articles are given below:

\section{Article 6: Cases of succession of States covered by the present articles}

The present articles apply only to the effects of a succession of States occurring in conformity with international law and, in particular, the principles of international law embodied in the Charter of the United Nations.

\section{Article 14: Questions relating to the validity of a treaty}

Nothing in the present articles shall be considered as prejudicing in any respect any question relating to the validity of a treaty.

Afghanistan argues ${ }^{42}$ that according to article 6 the Convention on State Succession covers only those cases of transfer of territority which take place in accordance with the principles of international law in general and those enshrined in the UN Charter in particular. In other words, in her view the Convention is only applicable to situations where treaties had been validly entered into between sovereign and independent States. It is worthy of note that Afghanistan attached so much importance to article 6 that if it was to be deleted she favoured a declaration rather than a convention on succession of States.

An application of the foregoing Afghan viewpoint to the concrete case results in the following Afghan contention. In 1893 when the Durand Agreement was signed between the Afghan Government and the British the former lacked capacity to enter into a treaty because Afghanistan was not an independent country as Britain was responsible for the latter's foreign relations. In other words, since the transfer of territory did not take place between two sovereign and independent States, the Agreement under which this was effected was at once invalid ab initio and contrary to the principles of the UN Charter. Therefore, so the argument runs, following the liquidation of the British Empire in India, Pakistan could not have succeeded to an agreement which suffered from invalidity from the outset and was repugnant to the Charter principles.

Pakistan does not see eye to eye with the foregoing Afghan interpretation. As far as the general Afghan position is concerned, Pakistan holds that the validity or operation of article 11 is not predicated upon any provisions of the Convention on State Succession or any other document. In other words, the mere fact of succession does not render a treaty

41 Ibid., pp. 113-15, paras. 10-20.

42 Ibid., pp. 49-50, paras 28-30 and p. 54, paras. 20-1. The representative of Pakistan also supported the retention of article 6 but wanted it to contain a ref erence to the Declaration of Principles of International Law concerning Friendly Relations and Cooperations between States. Ibid., p. 53, paras. 14-6. 
establishing a boundary regime invalid. If any principle or factor rendered a treaty null and void, it did so before as well as after the succession. It was a vitiating factor which was constantly there. The succession in itself did not introduce any element which invalidated a treaty. This is true about the Durand Agreement as well and thus after emerging as an independent State, Pakistan rightfully succeeded to the Durand Agreement in her capacity as successor to the British Indian Empire. This was confirmed by the predecessor State at least on two occasions. Speaking in the House of Commons, Mr. Noel-Baker, the British Secretary for the Commonwealth Relations made the following statement on 30 June 1950:

It is His Majesty's Government's view that Pakistan is in international law the inheritor of the rights and duties of the old Government of India, and of His Majesty's Government in the United Kingdom, in these territories, and that the Durand Line is the international frontier. ${ }^{43}$

On 1 March 1956, Mr. Anthony Eden, the British Prime Minister, made the following statement in the House of Commons:

Her Majesty's Government regard her [Pakistan] as having, with full consent of the overwhelming majority of the Pashtu-speaking peoples concerned, both in the administered and non-administered areas, succeeded to the exercise of the powers formerly exercised by the Crown in India on the North-West Frontier of the sub-continent. Her Majesty's Government in the United Kingdom fully support the Government of Pakistan in maintaining their sovereignty over the areas east of the Durand Line and in regarding this Line as the international frontier with Afghanistan. ${ }^{44}$

As far as the specific Afghan contention is concerned according to which the Durand Agreement did not devolve upon Pakistan because it was concluded between two unequals, it is rejected by the International Law Commission in these words:

After studying the various historical types of dependent territories (colonies, tursteeships, mandates, protectorates, etc.), the Commission concluded that their characteristics do not today justify differences in treatment from the standpoint of the general rules governing succession of States in respect of treaties. The Commission recognized that in the traditional law of succession of States, protected States have in some degree been distinguished from other dependencies of a State. Thus, treaties of the protected States concluded prior to its entry into protection have been considered as remaining in force; and treaties concluded by the protecting Power specifically in the name and on behalf of the protected State have considered as remaining in force for the protected State after termination of the protectorate. ${ }^{45}$ 
It follows from the above quotation that the Afghan contention is not justified and despite the act that Afghanistan was not a truly independent state in 1893, she is bound by the Agreement concluded at that time on her behalf by the protecting Power.

The other article on which Afghanistan bases its interpretation of article 11 is article $14^{46}$ which covers the entire subject of grounds of invalidity of treaties dealt with in articles 42 to 64 (part V) of the Vienna Convention. This article is couched in general terms. Though Afghanistan invokes this article, she relies more on the specific provisions of part V (articles 50, 52, 53 and 62(2) to be precise) of the Vienna Convention, as seen above, to challenge the validity of the Durand Agreement. These provisions have already been reated above and need no further comments.

\section{B) Subsequent conduct}

It is worth mentioning here that whereas Afghanistan interprets article 11 of the Convention on State Succession in the light of articles 6 and 14 she fails to refer to article $24(1)$ of the same instrument. Similarly in the interpretation of article 62 of the Vienna Convention, she makes no allusion to its article 45 . Before proceeding further the provisions of articles 24 and 45 are given a follows:

Article 24: Conditions under which a treaty is considered as being in force in the case of a succession of States

1. A bilateral treaty which, at the date of a succession of States was in force in respect of the territory to which the succession of States was in force in respect of the territory to which the succession of State relates, is considered as being in force between a newly independent State and the other State party when:

a) they expressly so agree; or

b) by reason of their conduct they are to be considered as having so agreed... (Emphasis added).

Article 45: Loss of a right to invoke a ground for invalidating, terminating, withdrawing from or suspending the operation of a treaty

A state may no longer invoke a ground for invalidating, terminating, withdrawing from or suspending the operation of a treaty under articles 46 to 50 or articles 60 to 62 if, af ter becoming aware of the facts:

a) It shall have expressly agreed that the treaty is invalid or remains in force or continues in operation, as the case may be; or

b) It must by reason of its conduct be considered as having acquiesced in the validity of the treaty or in its maintenance in force or in operation, as the case may be. (Emphasis added).

46 It is to be noted that the representative of Pakistan was of the view that article 14 was not really necessary because it enshrined a selfevident rule. However, he did not object to its inclusion in the convention. $U N$ Conference on Succession of States, first session, supra note 38, p. 153, paras. 11-2. 
The foregoing two articles refer to the principle of "subsequent conduct" which is an important principle of interpretation of treaties and which signifies that "[i]nterpretation placed upon instruments by the parties to them, through not conclusive as to their meaning, have considerable probative value when they contain recognition by a party of its own obligations under an instrument $" .{ }^{47}$ The relevance of this principle in the present situation is as follows. Since Afghanistan contends that the Durand Agreement was invalid, it is not unreasonable to assume that subsequent to 1893 when the said Agreement was signed Afghanistan must have treaty is as such.

\section{a) Subsequent agreement}

Here below we propose to study the three treaties which were entered into subsequent to the Durand Agreement and which on the face of it endorse the Indo-Afghan frontier as spelled out in the latter Agreement. We also propose to examine the subsequent practice of Afghanistan in the matter. The analysis will show that Afghanistan either did not question the validity of the Durand Agreement until recent times or expressly endorsed it.

\section{1) Anglo-Afghan Pact of 1905}

The first instrument to be considered is the Anglo-Afghan Pact of 1905 (also called Dane-Habibullah Treaty) which provides in its relevant part as follows:

His said Majesty does hereby agree to this that in the principles and in the matters of subsidiary importance of the engagements which His Highness my late father (Abdurrahman) concluded and acted upon with the Exalted British Government, I also have acted, am acting and will act upon the same agreements and compacts, and I will not contravene them in any dealing. ${ }^{48}$

Three principal objections are advanced against it. ${ }^{49}$ Firstly, the Pact was couched in personal terms which implied personal commitment on the part of Habibullah but did not bind the State of Afghanistan. Secondly, the Pact suffers from imprecision and lack of specificily as no mention of the Durand Line is made. Thirdly, the circumstances in which the Pact was concluded show that it was not meant to be anything more than a mutual expression of good will. (The Russo-Afghan relations had deteriorated but in view of the 1907 Anglo-Russian Convention which was in the offing the British negotiators refused to make any firm commitments against Russia. Following this the disgruntled Afghans were less than enthusiastic about the agreement to which the British

47 ICJ Reports 1950 , p. 136.

48 Olaf Caroe, The Pathans, supra note 1, p. 464.

49 L. Poullada, "Pushtunistan: Afghan domestic politics and relations with Pakistan", in A. T. Embree (ed.), Pakistan's Western Border-lands, Carolina Academic Press: Durham/North Carolina, 1977, pp. 139-40. 
reacted by seriously contemplating to break off negoitations. The 1905 Pact was concluded with this background).

As far as the first objection is concerned, on the basis of the language used in the 1905 Pact the undertaking appears to have been made by the Amir in his personal capacity. If this is true what are its implications in terms of international law? In other words, does this mean that the Pact was valid and binding as far as the Amir was concerned but did not bind Afghanistan. But if this view is not acceptable and the Pact bound Afghanistan from the outset as no distinction is possible between the Amir and the country he represented, perhaps it could be argued that the Pact lapsed with the departure of the Amir as the head of his country.

Looking at the distinction between treaties which are personal in nature and those which are contracted in a representative capacity, international law, both traditional and modern, does not make any distinction between them on this ground. A treaty accepted by the head of a Government or State or their representives is done on behalf of the State and not in personal capacity. ${ }^{50}$ Article 7, paragraph 2(a) of the Vienna Convention recognizes this point in these words:

2. In virtue of their functions and without having to produce full powers, the following are considered as representing their State:

a) Heads of State, Heads of Government and Ministers for Foreign Affairs, for the purpose of performing all acts relating to the conclusion of a treaty...

The International Law Commission's commentary on the foregoing paragraph has this to say:

(It sets out) three categories of case in which a person is considered in international law as representing his State without having to produce an instrument of full powers. In these cases, therefore, the other representatives are entitled to rely on the qualification of the person concerned to represent his State without calling for evidence of it. ${ }^{51}$

Additionally, the judgment of the Permanent Court in the Legal Status of Eastern Greenland case of 1933 may be cited in the present context. In that case even an oral declaration (the Ihlen Declaration) in the nature of a promise by the Norwegian Foreign Minister within his competence and authority was held to be binging as a formal written treaty. ${ }^{52}$ In the light of the foregoing and in view of the fact that Afghanistan was an absolute monarchy in 1905 with no room for constitutionalism, the plea of the Pact being a personal engagement of the part of the Amir is simply not available. If no distinction is to be made between personal and impersonal treaties then the contention

50 Oppenheim-Lauterpacht, International Law, Longmans, Green and Co.: New York/London/Toronto, 1955, 2 vols., I:884.

$51 \quad$ ILC Yearbook, supra note 13, p. 193, para. 4

52 P.C.I.J. (1933), Series A/B, No. 53, p. 71. 
that the Pact lapsed with the departure of the Amir as the ruler becomes untentable for the simple reason that it created rights and obligations between Afghanistan and the other contracting party and its survival did not depend on the existence or disappearance of a particular individual or dynasty.

As to the second objection, it is true that the Pact suffers from lack of specificity as no mention of the Durand Agreement as such is made. But if its text is couched in general language does it imply that the intentions of the contracting parties become vague and imprecise. Undoubtedly a precise and specific reference to the Durand Agreement would have endowed the Pact with greater probative value but the use of a general language by no means belittles its importance still less of making the intentions unclear. An interpretation in good faith of the "engagements which ... (Abdur Rahman) concluded ... with the Exalted British Government" would clearly refer, inter alia, to the Durand Agreement because it was one of the most important, if not the most important, agreements concluded between the two.

As to the third objection which says that the Pact was no more than a mutual expression of good will by the parties would signify that they did not intend legal consequences to flow from it. Such a view is unacceptable as being contrary to the very notion of treaty-making which is the creation of legal relations between parties. However even if this view was accepted as valid, cognizance cannot be taken of it unless, as the ICJ said in the 1966 South West Africa case (2nd phase), it is given "a sufficient expression in legal form ". ${ }^{53}$ The language of the Pact does not seem to indicate that such was the intentions of the parties. On the contrary, as testified by subsequent events, they looked upon the Pact as embodying solemn legal undertakings towards each other. If this was not the case, the Treaty of Rawalpindi would not refer in its article 5 to the provisions of the Pact in order to show that the Afghan Government accepts the Durand Line.

\section{2) Treaty of Rawalpindi of 1919}

The second instrument to be considered is the Treaty of Rawalpindi of 1919, whose article 5 states as follows: "The Afghan Government accepts the Indo-Afghan Frontier accepted by the late Amir Habibullah". ${ }^{54}$ It has been maintained ${ }^{55}$ that despite the categorical nature of the statement made here, it must be kept in mind that the Treaty of 1919 was an ad hoc arrangement in the nature of an armistice meant to regulate relations between the parties at the conclusion of the third Anglo-Afghan War. Therefore its provisions on the Indo-Afghan frontier needs to be treated with circumspection. Additionally it cannot be valued highly because it was expressly stipulated by the contracting parties to replace it by a treaty of permanent nature which was done in 1921 . The above Afghan objections are untenable. To begin with, there is no rule of interna-

53 ICJ Reports 1966, p. 34.

54 Olaf Caroe, The Pathans, supra note 1, p. 464.

55 L. Poullada, "Pushtunistan". supra note 49, p. 140. 
tional law according to which certain provisions would be devoid of any legal effect or carry lesser weight simply because they happen to be part of an agreement of a temporary nature rather than of a permanent kind. Treaties are not interpreted in international law on the basis of the period of their duration but rather according to stipulations contained therein. If the Afghan contention was right the Anglo-Afghan Treaty of 1921 dealing with the Indo-Afghan frontier in article 2 would not refer to article 5 of the 1919 Rawalpindi Treaty. Again if this treaty which was basically an armistice agreement meant to regulate problems of immediate character could address the important issue of the grant of independence to Afghanistan and full legal effect could be given to its provisions relating to the latter aspect why its provisions which reaffirmed the Durand Agreement would not be given the same effect? There is no principle of international law which would justify according greater weight to certain provisions and lesser the others in a treaty. The analogy of concepts of ratio decidendi and obiter dicta which exist in a judicial pronouncement cannot be extended to the present situation. Consequently, we may conclude that by virtue of article 5 of the Treaty of Rawalpindi the Afghans firmly and unequivically endorsed the Durand Agreement. The reference to the Anglo-Afghan Pact of 1905 does not water down the Afghan commitment because the latter agreement, as shown above, fully bound the Afghan Government.

\section{3) Anglo-Afghan Treaty of 1921}

The next instrument to be consedered in connection with the endorsement or otherwise of the Durand Agreement is the Anglo-Afghan Treaty of 1921 which has the following provisions on the frontier question and tribal areas:

2. The two high contracting parties mutually accept the Indo-Afghan frontier as accepted by the Afghan Government under Article 5 of the treaty concluded on the 8th August, 1919.

11. The two high contracting parties, being mutually satisfied themselves each regarding the good will of the other and especially regarding their benevolent intentions towards the tribes residing close to their respective boundaries, hereby undertake each to inform the other in future of any military operations of major importance which may appear necessary for the maintenance of order among the frontier tribes within their respective spheres, before the commencement of such operations. ${ }^{56}$

By virtue of the above article 2 the Afghan Government reaffirmed its acceptance of the Durand Line as the Indo-Afghan frontier. This has been done by referring to the Afghan commitment in the matter as contained in the 1919 Treaty of Rawalpindi which in turn referred to the one made in the Anglo-Afghan Pact of 1905 both of which, as shown above, were firm and unequivocal commitments.

By virtue of the above article 11 the two parties undertook to inform each other of major military operations in tribal areas which where within their respective spheres. This

56 Olaf Caroe, The Pathans, supra note 1, p. 464. 
provision no more than describes an arrangement which suited the British and Afghan security interests in the area at that time. However, a letter from the British respresentative to the Afghan Foreign Minister which supplemented the Anglo-Afghan Treaty of 1921 carried the following provisions:

As the conditions of the frontier tribes of the two governments are of interest to the Government of Afghanistan, I inform you that the British Government entertains feelings of good will toward all the frontier tribes and has every intention of treating them generously provided they abstain from outrages against the inhabitants of India. I hope this letter will cause you satisfaction. ${ }^{57}$

What is the meaning of the British recognition of the Afghan "interest" in the tribesmen inhabiting either side of the Durand Line? Does it impliedly suggest the British acceptance of their lack of sovereignty over the territory leading upto the Durand Line? According to the Webster's Third New International Dictionary the word "interest" signifies "the state of being concerned or affected especially with respect to advantage or well-being". If the British made this concession in favour of Afghanistan it meant no more than recognition of the close linguistic, ethnic and religious affinities between the Afghans on either side of the Durand Line. It was meant to convey a message of goodwill and good neighbourly relations towards Afghanistan with the view to securing the latter's co-operation in controlling and pacifying the frontier tribesmen on the Indian side of the Durand Line over whom she exercised considerable influence. The said provision cannot be construed to mean complete or partial negation of the British sovereignty in the area for a variety of reasons. Firstly, the plain text of the letter in question does not permit such an interpretation. Secondly, such an interpretation would be at variance with article 2 of the main treaty (the Anglo-Afghan Treaty of 1921) of which the letter is claimed to be a part and which put a seal of approval on the Durand Line as constituting the Indo-Afghan frontier. Such a construction is unacceptable because it would defeat one of the most important provisions of the Anglo-Afghan Treaty of 1921. Thirdly, the subsequent British or Afghan conduct upto almost 1947 when the former decided to quit India does not support such an interpretation. On the contrary, in May 1930 an exchange of letters between the British Foreign Secretary and the Afghan Minister in London indirectly confirmed the Indo-Afghan frontier. Thus to the British affirmation ${ }^{58}$ "that these Treaties (of 1919 and 1921) continue to have full force and effect", the Afghan reply endorses this viewpoint and does not attempt to qualify it by alluding to the said letter containing a text supposedly negating the British sovereignty over the frontier tribesmen. One may conclude that the Anglo-Afghan Treaty of 1921 endorses the Durand Agreement and the letter which supplemented it does not whittle down that commitment. 


\section{b) Subsequent practice}

During the period 1921-45 the Durand Agreement continued to be regarded as a valid treaty between Afghanistan and the British India ${ }^{59}$ not only through the subsequent agreements entered into between the two, as seen above, but also through their practice. In this respect it may be pertinent to point out that when the Government of India Act of 1935 formally defined ${ }^{60}$ India as incorporating the "Tribal Territory" as it was delineated on the Indian official maps, no protest against it was lodged by Afghanistan to the British Indian Government. It was only about the middle of the 1940s when the British departure from India was looking more and more certain that the Afghan Government made a representation to Britain that the frontier tribes be accorded the option to become independent or join Afghanistan. ${ }^{61}$ With the announcement of the Partition Plan on 3 June 1947, a further challenge to the Durand Agreement was thrown when the Afghan Government asked the departing British authorities to allow the Pakhtuns to opt for independence in addition to the choice between Pakistan and India which they were to exercise in the forthcoming referendum in the North-West Frontier Province. This challenge to the Durand Agreement surfaced at the United Nations in September 1947 when, speaking on the question of Pakistan's request for membership, her representative declared: "We cannot recognize the North-West Frontier as part of Pakistan. "62 Later on in July 1949 the Afghan Loya Jirga, the Afghan Parliament, made a declaration in which it refused to "recognize the imaginary Durand or any similiar line" ${ }^{63}$

It is clear from the foregoing narration of facts that for about half a century following the conclusion of the Durand Agreement, Afghanistan accepted the latter as a valid and binding treaty. If it's validity was questioned at about the time of the British departure from India and subsequently after the emergence of Pakistan as an independent State the Afghans might have been guided by a variety of reasons such as the prospect of either converting the British to their viewpoint or getting their claim accepted by weak Pakistan. Whatever the motivations for which Afghanistan rejected the Durand Agreement

59 It is to be noted that in an interview with Izvestia in $1928 \mathrm{King}$ Amanullah stated that $n$ the belt of independent tribes, ... must under Afghan national policy, be incorporated into Afghanistan, to which they belong by tribal relationship and economic ties" (Burke, Pakis tan's Foreign Policy, supra note 16, p. 84). It is doubtful if this statement could be construed to mean more than an expression of irredentist fantasy. It is difficult to interpret it as a rejection of the treaties pertaining to the Durand Line. And even if it is looked upon in the latter sense, because of the isolated nature of this statement it does not affect our position in the matter as it comes out in the text.

60 Ibid., p. 68. According to Dupree following the end of World War II when it became clear that the British would grant independence to India, the Afghan Government through a letter dated 1944 questioned the Durand Line by indicating to the latter her interest in the future of Paghtuns on the Indian side. L. Dupree, Afghanistan, supra note 23, p. 488.

61 Mujtaba Razvi, The Frontiers of Pakistan, supra note 2, p. 151.

62 Ibid., p. 153.

63 Ibid., p. 150. 
her acceptance of it for about 50 years since its conclusion in 1893 estoppes her from denying it as a valid treaty.

Here a word about the Afghan Loya Jirga's declaration by virtue of which it denounced the Durand Agreement and the subsequent treaties affirming it as null and void is in order. The question is whether the denunciation of the latter treaties by the Afghan Parliament could release Afghanistan from the obligations she took upon herself with regard to the Indo-Afghan frontier. These treaties, excepting the 1921 Treaty, ${ }^{64}$ do not carry provisions for releasing a party unilaterally from the treaty obligations and are therefore perpetual treaties. Article 56 of the Vienna Convention addresses this question in these terms:
Article 56 - Denunciation of or withdrawal from a treaty containing no provision regarding termination, denunciation or withdrawal
1. A treaty which contains no provision regarding its termination and which does not provide for denunciation or withdrawal is not subject to denunciation or withdrawal unless:
a) it is established that the parties intended to admit the possibility of denunciation or withdra- wal; or
b) a right of denunciation or withdrawal may be implied by the nature of the treaty...

According to the foregoing article a right of denunciation or withdrawal from a treaty can be exercised in the following three situations: a) when such right is provided in the treaty; b) when it is established that the parties so intended; c) when such right is implied in the treaty. As far as the treaties mentioned above, but especially the Durand Agreement, are concerned, the provisions of article 56 would not apply as they do not fall into either of the three categories. This is admitted by the ILC commentary on the foregoing article when it says: ". . [T] he very character of some treaties excludes the possibility that the contracting States intended them to be open to unilateral denunciation or withdrawal

64 The Anglo-Afghan Treaty of 1921 was not a perpetual treaty as its article XIV laid down the procedure for withdrawal or denunciation by either party in these words:

The provisions of this Treaty shall come into force from the date of its signature, and shall remain in force for three years from that date. In case neither of the High Contracting Parties should have notified twelve months before the expiration of the said three years the intention to terminate it, it shall remain binding until the expiration of one year from the day on which either of the High Contracting Parties shall have denounced it. On November 21, 1953, Afghanistan notified the termination of the Anglo-Afghan Treaty of 1921. It is interesting to note that the termination notice was sent to the predecessor State Great Britain and not the successor State Pakistan. Here the question arises as to the status of the foregoing Treaty, especially of the provision relating to the boundary settlement in view of the division of the British India into independent States of India and Pakistan. The position of the British Foreign Office in the matter which was approvingly cited by the International Law Commission in its report was as follows:

The Foreign Of fice were advised that the splitting of the former India into two States - India and Pakistan and the withdrawal of British rule from India had not caused the Afghan Treaty to lapse and it was still in force. It was nevertheless suggested that an examination of the Treaty might show that some of its provisions being political in nature or relating to continuous exchange of diplomatic missions were in the category of those which did not devolve where a State succession took place. However, any exetuted clauses of the Treaty, could not be affected, whatever the position about the Treaty itself might be.

Materials on State Succession, supra note 30, p. 187. 
at the will of an individual party. Treaties of peace and treaties fixing a territorial boundary are examples of such treaties. ${ }^{65}$ Consequently, notwithstanding the Afghan denunciation of the Durand Agreement and other relevant treaties she is not released from the obligations accepted by her through them.

The Afghan denunciation of the Durand Agreement and other related treaties perhaps also signify that they do not support the Afghan contention in the matter. If this were not so the Afghan Parliament and the Afghan Government would not have repudiated them.

\section{Conclusion}

The foregoing analysis of the relevant provisions of the Vienna Convention and the Convention on State Succession shows that they do not support the Afghan stand on the Durand Agreement. Consequently it is highly unlikely that Afghanistan would become a party to these Conventions. Already she has entered declarations by virtue of which she has made known its understanding or reservations on certain provisions discussed above. In the light of these facts Pakistan would be well advised to become a party to these Conventions by ratifying them as early as possible.

65 ILC Yearbook, supra note 13, p. 250, para 2. 


\section{ABSTRACTS}

\section{The Durand Agreement in the Light of Certain Recent International Conventions}

\section{By Ijaz Hussain}

Pakistan's frontier with Afghanistan in the north-west known as the Durand Line came about as a result of the Durand Agreement concluded in 1893 between the British Indian and Afghan Governments. Since 1947 when Pakistan emerged as an independent State, Afghanistan has on a number of grounds challenged the validity of the Durand Agreement and hence the resulting boundary line. This question is studied in the light of two conventions, namely the 1969 Vienna Convention and the 1978 Convention on State Succession because they more or less cover all the grounds which are invoked by Afghanistan in favour of its claim. Articles 50; 52; 53 and 62 of the former convention dealing with arguments of corruption, coercion, jus cogens, and rebus sic stantibus respectively and articles 11 and 24 of the latter convention concerning boundary regimes and subsequent conduct respectively are treated at length in order to evaluate the Afghan contention on the Durand Agreement. This analysis shows that they do not support the Afghan contention in the matter.

\section{Colonial Law and the Inception of a Dual Land System in Nyasaland}

\section{By Clement $N g^{\prime}$ ong'ola}

This paper re-examines Barry Johnston's important land settlement in colonial Malawi with the aim of exploring how colonial law and legal institutions reacted to the conflicts and controversies which it engendered. This exercise should provide fresh insights into how Johnston personally conducted the settlement, and by focussing on "legal issues", add the missing element to existing historiographical accounts. The exercise should also yield information to support the view in contemporary debates on law and development that as compared to social, political and administrative factors, legal rules may have a relatively minor role to play in the ordering of society. 